\title{
A RAMAN SPECTROSCOPY STUDY OF THE POLYANILINE ELECTRODE ON ZN-POLYANILINE RECHARGEABLE BATTERIES
}

\author{
Said Ali Akbar ${ }^{1, *}$, Achmad Rochliadi², Veinardi Suendo², Nurdin Saidi ${ }^{3}$, \\ Lelifajri $^{3}$ and Ainun Mardhiah ${ }^{1}$ \\ ${ }^{1}$ Department of Chemical Education, Serambi Mekkah University, 23245, \\ Banda Aceh, Aceh, Indonesia \\ ${ }^{2}$ Department of Chemistry, Bandung Institute of Technology, 40116, Bandung, \\ West Java, Indonesia \\ ${ }^{3}$ Department of Chemistry, Syiah Kuala University, 23111, Banda Aceh, Aceh, Indonesia \\ *E-mail : said.aliakbar@ serambimekkah.ac.id
}

\begin{abstract}
Due to its limiting factor of the cycle-life on Zn-polyaniline (PANI) rechargeable battery, the surface morphology and electrochemical properties have been extensively investigated. However, there are no studies that found on the chemical structure of PANI electrode before and after used in the battery with spectroscopy. Here, the Zn-PANI Battery was tested through a 60-cycle discharging process using $10 \mathrm{~mA}$ fixed current. The Open Circuit Voltage $(\mathrm{OCV})$ at this condition was $\pm 1.3 \mathrm{~V}$. The Raman spectra at $488 \mathrm{~nm}$ on PANI discharge showed increasing intensity at $1495 \mathrm{~cm}^{-1} v(\mathrm{C}=\mathrm{N})$. Furthermore, the new peak appeared on the band at $1212 \mathrm{~cm}^{-1} \mathrm{v}(\mathrm{N}=\mathrm{Q}=\mathrm{N})$ and $1166 \mathrm{~cm}^{-1} \mathrm{v}(\mathrm{C}-$ $\mathrm{H}$ ), related to mode on the benzenoid ring. This investigation indicated the formation of Emerald in Bases (EB), caused by the consumption of protons by $\mathrm{Zn}$ metal during the filling process.

Keywords: Polyaniline, open circuit voltage, raman spectra, rechargeable batteries, specific capacity

(C) RASĀYAN. All rights reserved
\end{abstract}

\section{INTRODUCTION}

Studies of applications the conductive polymers such as polyaniline (PANI) has been very interesting and attractive in electronic devices due to its easy to synthesis, high conductivity, unexpensive material, stability in aqueous solutions, stability in high temperature and good redox reversibility. ${ }^{1-12}$ For its applications are reported to be promising materials for future technologies, such as rechargeable batteries, sensors, conductive paints, corrosion avoidance, electrocatalysis, solar cell, extraction, and capacitors. PANI can be synthesized in among of isolation form such as fully oxidized Pernigranilin Base (PNB), semi-oxidized Emeraldine Base (EB), and fully reduced Leucomeraldine Base (LEB). ${ }^{13,14}$ Of these three forms, the most stable and widely observed is EB form because the conductivity can be adjusted from $10^{-10}-100$ S. $\mathrm{cm}^{-1}$ by protonated with acid doping. ${ }^{16}$ Furthermore, PANI can also be oxidized spontaneously in the aqueous acidic solutions, which is very proper for the capacity recovery of the battery. Therefore, the aqueous batteries of the PANI synthesized have been extensively studied. ${ }^{16,20}$

The considerable interest of PANI-base batteries development has accelerated, typically, aqueous $\mathrm{Zn}$ PANI batteries composed of a zinc anode and PANI cathode with aqueous electrolyte consist $\mathrm{Zn}^{2+}$ ion in Triton X-100 as a surfactant. In comparison with classical batteries, these batteries indicate a lot of benefit such as: ecological acceptability, the stability of redox reaction, low cost, and easy fabrication. However, Zn-PANI rechargeable battery denotes a degression in capacity during charge-discharge cycling process, there is very little experimental information on how this limitation can occur. ${ }^{15}$

The effect of inhibitors on Zn-dendrite formation for Zn-PANI secondary battery has been investigated. These results show that Triton $\mathrm{X}-100$ can effectively prevent $\mathrm{Zn}$-dendrite growth during charge-discharge

Rasayan J. Chem., 11(4), 1525-1531(2018)

http://dx.doi.org/10.31788/RJC.2018.1144064

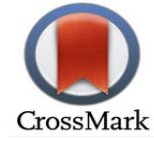


cycles process of the Zn-PANI battery with an acid medium and give longer cycles. So, It is possible that Triton X-100 can be contributed as an effective additive in the rechargeable Zn-PANI batteries. ${ }^{12}$ Than, the electrochemical and surface analysis techniques to investigation affect the cycle-life of a Zn-PANI secondary battery have proposed that zinc passivation can significantly reduce the battery capacity. It arises that the kinetics of $\mathrm{Zn}$ passivation is faster than PANI electrochemical degradation. Consequently, $\mathrm{Zn}$ passivation is the main determinant of the cycle-life of Zn-PANI secondary batteries. ${ }^{19}$ However, there is no information investigated the bonding structure of the PANI electrode before and after is used as a battery.

In the work reported here, we have observed the factors that affect the cycle-life of a Zn-PANI secondary battery by means of Raman spectroscopy techniques on PANI electrode.

\section{Material}

\section{EXPERIMENTAL}

The aniline monomer (Aldrich, 99.5\%) was distilled under vacuum, ammonium peroxydisulfate (APS) was purchased from Sigma Aldrich, 37\% hydrochloric acid ( $\mathrm{HCl})$, graphite sheet (GS), ammonia $\left(\mathrm{NH}_{3} \cdot \mathrm{H}_{2} \mathrm{O}\right)$, acetone, zinc chloride $\left(\mathrm{ZnCl}_{2}\right)$, Dimethyl acetamide (DMAC), Triton $\mathrm{X}-100$, and Whatman filter paper No. 42. Doubly-distilled water was used in all experiments

\section{Synthesis of PANI}

PANI was prepared by chemical polymerization method from a solution containing $0.20 \mathrm{M}$ aniline, $1 \mathrm{M}$ $\mathrm{HCl}$ and 0.3 Mammonium persulfate at $5{ }^{\circ} \mathrm{C}$ on GS surface with $4 \mathrm{~cm}^{2}$ area of deposition. Furthermore, the solution was introduced into the cell with 3 electrodes, Pt metal as a counter electrode, GS as the working electrode, and $\mathrm{Ag} / \mathrm{AgCl}$ (in saturated $\mathrm{KCl}$ solution) as the reference electrode. The polymerization process is carried out at a constant voltage of $0.7 \mathrm{~V}$ using Gamry Reference 3000 for 15 minutes. ${ }^{10-11}$ The coated electrode with PANI was washed with distilled water and acetone to remove oligomer that formed on the surface until the filtrate became almost colorless. The oligomer is possible to decrease the conductivity of polyaniline. ${ }^{15}$ The resulting emerald polyaniline was obtained and rinsed with $1 \mathrm{M} \mathrm{HCl}$ to perfect doping again and dried at $70{ }^{\circ} \mathrm{Cin}$ vacuum oven overnight. ${ }^{17-18}$ The amount of the deposits can be simply determined by weighting the electrode before and after the deposition process. It is of importance to determine the exact mass of the electroactive material for the estimation of the specific capacity of the battery. ${ }^{6}$

\section{Fabrication of $\mathrm{Zn}_{\mathrm{ZnCl}}$ (Electrolyte)||PANI-CI|GS Batteries}

The discharge process is performed for battery performance testing. The battery system configuration consists of $\mathrm{ZnIZnCl}_{2}$ (electrolyte) $\| \mathrm{PANI}-\mathrm{Cl} \mid \mathrm{GS}$. In this case, PANI as cathode and zinc metal as the anode. The filter paper is used as a separator which is injected with $1 \mathrm{M} \mathrm{ZnCl}_{2}$ electrolyte with adjusted $\mathrm{pH}$ with $0.5 \mathrm{M} \mathrm{NH}_{4} \mathrm{Cl}$. The Triton $\mathrm{X}-100$ surfactant is also added to the electrolyte to prevent the formation of dendrites in zinc. ${ }^{12}$ This process uses a fixed current of $10 \mathrm{~mA}$ for 60 cycles. The cut off on the charging process is $1.57 \mathrm{~V}$, while the emptying process is $0.7 \mathrm{~V}$. The precondition is carried out at the beginning of the cycle with a $1.65 \mathrm{~V}$ charging cut off, and $0.1 \mathrm{~V}$ discharging. This precondition aims to maximize the reaction occurring at PANI electrode. ${ }^{19}$

\section{Detection Method}

The PANI of the synthesis was characterized by FT-IR spectroscopy, PANI in press together with $\mathrm{KBr}$ to form PANI pellet in $\mathrm{KBr}$ matrix, then analyzed by Bruker Alpha FTIR, with a range of wave number $4000-550 \mathrm{~cm}^{-1}$ and scanning counted 16 times. PANI is also characterized by UV-Vis using Thermo Scientific Evolution 220 Series UV-Visible Spectrophotometer, with a wavelength range of $300-1100$ $\mathrm{nm}$ in Dimethyl acetamide (DMAC) solvent. ${ }^{19}$ Raman spectroscopy studies were performed on PANI before and after use as battery electrodes. The sample was measured by the Raman Bruker Senterra spectrometer and focused so that the right rays illuminated the sample. The measuring conditions use a laser with a wavelength of $488 \mathrm{~nm}$ (blue), with $4 \mathrm{~mW}$ power, MPlan 20x (short focal) and high resolution (grating 1200 grooves $/ \mathrm{cm}$ ) and a measuring $\mathrm{x} 4$ time of $10 \mathrm{~s}$. 


\section{Characterization of PANI}

\section{RESULTS AND DISCUSSION}

The results of the FT-IR measurements of PANI synthesized are shown in Fig.-1. The bands at 1562 and $1479 \mathrm{~cm}^{-1}$ corresponds to the stretching modes of $v(C=C)$ strain on the quinonoid ring and $v(C=C)$ on the benzenoid ring. ${ }^{13,19}$ The peak at $1479 \mathrm{~cm}^{-1}$, seen slightly higher than at $1560 \mathrm{~cm}^{-1}$. This shows that the synthesized polyaniline has a greater number of benzenoid rings than the quinoid rings. Furthermore, the peak on the area of 1302 and $1246 \mathrm{~cm}^{-1}$ assigned to $v(\mathrm{C}-\mathrm{N})$ stretching of secondary aromatic amine and $v\left(\mathrm{C}-\mathrm{N}^{+} \bullet\right)$ stretching on the polarone lattice. ${ }^{20}$ The peak at $1140 \mathrm{~cm}^{-1}$ is assigned to $v(\mathrm{Q}=\mathrm{NH}+\mathrm{B})$ or $v(\mathrm{Q}-$ $\mathrm{NH} \bullet+-\mathrm{B})$ stretching, the region of PANI intensity is higher than PANI EB. Hence, the FT-IR spectrum corresponds to well-doped PANi-ES. ${ }^{25}$

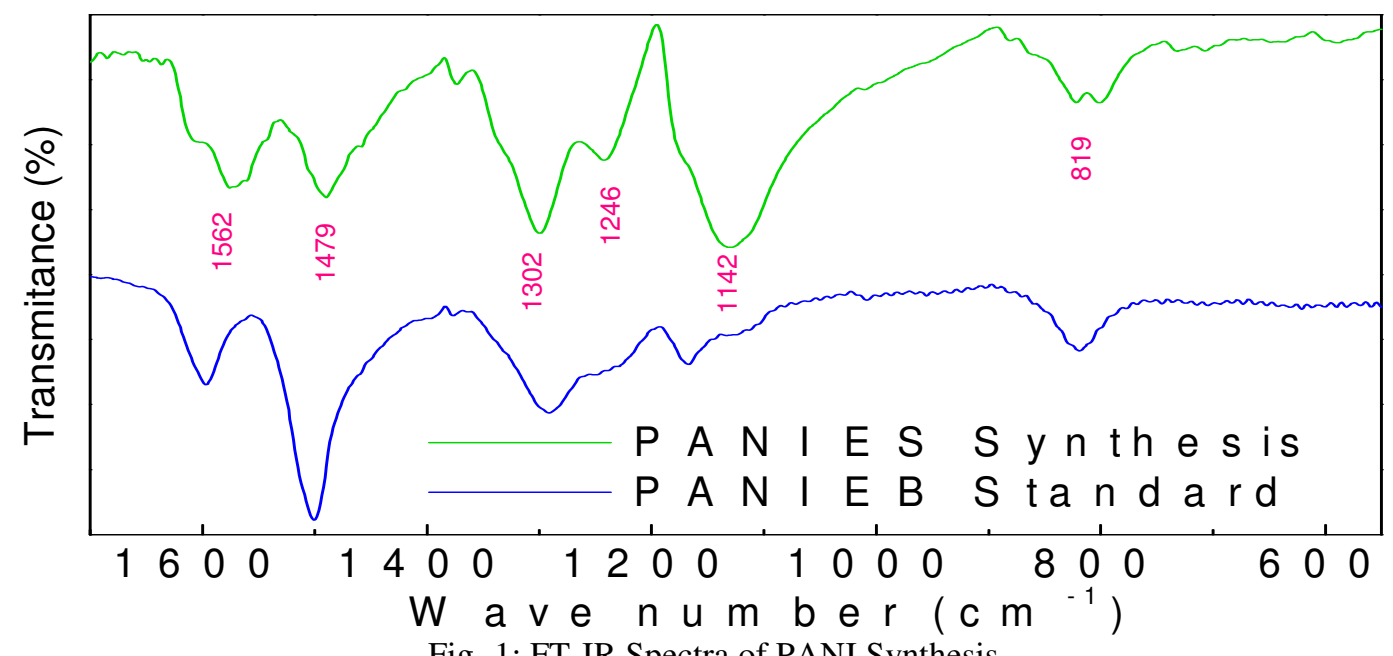

Fig.-1: FT-IR Spectra of PANI Synthesis.

Figure-2 displays the UV-Vis absorption spectra obtained from PANI synthesized compare with PANI EB standard. There are four typically indicated electronic transitions on PANI synthesized, whereas a standard PANI EB has only 2 transition types. At the absorption bands at 326 and $443 \mathrm{~nm}$ appropriated with an electronic transition of $\pi_{b}-\pi_{b}{ }^{*}$ and polaron $-\pi_{q}{ }^{*}$. Next, absorption bands at 617 and $930 \mathrm{~nm}$ assigned to the transition of $\pi_{b}-\pi_{q}{ }^{*}$ and $\pi_{b}$-polaron. On the UV-vis absorption pattern, there are no bands appear at 443 and $930 \mathrm{~nm}$ due to its no polaron in EB formation. ${ }^{15}$

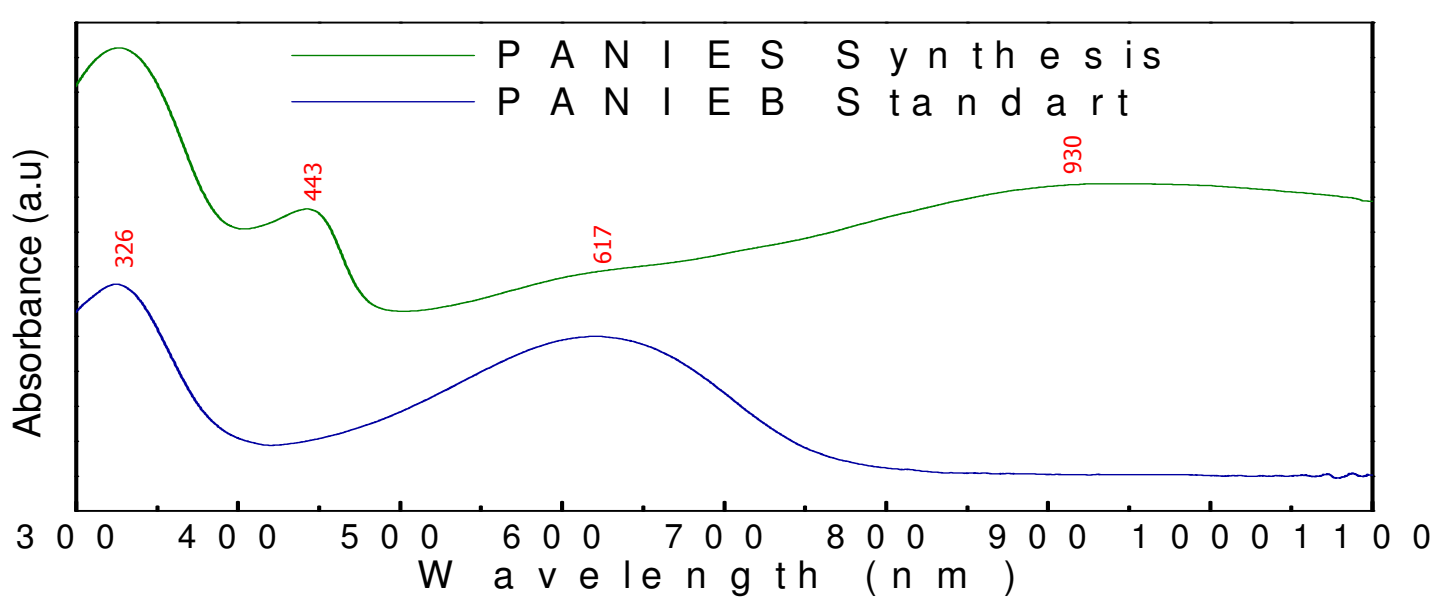

Fig.-2: Visible Spectra of PANI Synthesis in DMAC Solvent.

\section{Battery Performance}

For charge-discharge cycling process of the Zn-PANI battery, a constant-current mode at $2.5 \mathrm{~mA} \mathrm{~cm}^{-2}$ was chosen. The open circuit voltage (OCV) and the first discharge specific capacity over pH 3.0-6.0 was given in Table-1. The maximal first discharge specific capacity $\left(222.25 \mathrm{mAh} \mathrm{g}^{-1}\right)$ was obtained at $\mathrm{pH} 3.0$, 
RASĀYAN J. Chem.

Vol. 11 | No. 4 |1525 - 1531| October - December | 2018

then shown slumping on 50.24mAh $g^{-1}$ at $\mathrm{pH}$ 6.0. This fact indicating the degradation of PANI is potentially dependent on the $\mathrm{pH}$ of the electrolyte solution.

Table-1: Open Circuit Voltage and the First Discharge Specific Capacity at pH 3.0-6.0

\begin{tabular}{c|c|c|c|c}
\hline $\mathrm{pH}$ & 3.0 & 4.0 & 5.0 & 6.0 \\
\hline $\mathrm{E}_{\text {ocv }}(V)$ & 1.34 & 1.3 & 1.28 & 0.7 \\
\hline $\mathrm{C}\left(m A h g^{-1}\right)$ & 222.25 & 192.25 & 125.23 & 50.24 \\
\hline
\end{tabular}

When increasing of $\mathrm{pH}$, the $\mathrm{OCV}$ and the first discharge specific capacity decline due to the decreased electrochemical activity of PANI. On the other hand, zinc electrode easily experienced corrosion in the $\mathrm{pH}$ lower than 4.0. So, the interval of $\mathrm{pH} 4.0-5.0$ is considered as the compatible $\mathrm{pH}$ range for the electrolyte. $^{24}$

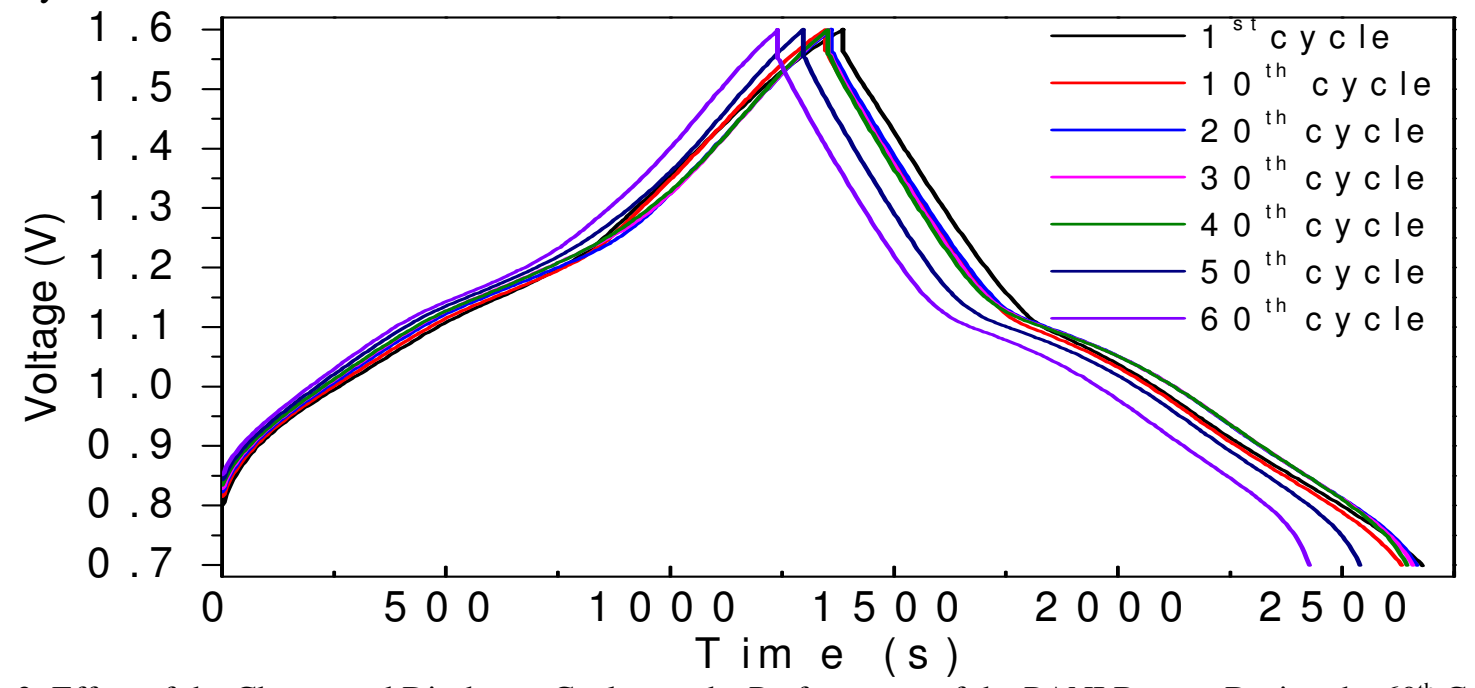

Fig.-3: Effect of the Charge and Discharge Cycles on the Performance of the PANI Battery During the $60^{\text {th }}$ Cycle

Scheme-1 schematically displayed the reactions take place during the charge-discharge process of the $\mathrm{Zn}$ PANI battery.As is obvious, when the battery is charged, the oxidized form of PANI is occurred along slowly increasing the voltage. Due to its degradation produced electrochemical inactive form when oxidation was completed, the charging process should be terminated with cut-off voltage (COV) reaching at $1.57 \mathrm{~V}$. This issue corresponded with overcharge leading to irreversible changes (electrochemical inactive form) in the chemical composition of the polymer. ${ }^{20,23}$

Table-2: Successive Constant Current Charge/Discharge Data of the Zn-PANI Battery

\begin{tabular}{|c|c|c|c|c|c|c|c|}
\hline \multirow[t]{2}{*}{ Cycle } & \multirow{2}{*}{$\begin{array}{c}\text { Average } \\
\text { charge } \\
\text { voltage }(V)\end{array}$} & \multirow{2}{*}{$\begin{array}{c}\text { Average } \\
\text { discharge } \\
\text { voltage }(V)\end{array}$} & \multicolumn{2}{|c|}{$\begin{array}{c}\text { Capacity density } \\
\left(m A h g^{-l}\right)\end{array}$} & \multicolumn{2}{|c|}{$\begin{array}{l}\text { Energy density } \\
\left(m W h g^{-I}\right)\end{array}$} & \multirow{2}{*}{$\begin{array}{c}\text { Coulombic } \\
\text { efficiency } \\
(\%) \\
\end{array}$} \\
\hline & & & Charge & Discharge & Charge & Discharge & \\
\hline $1^{\text {st }}$ & 1.135 & 1.135 & 192.36 & 179.72 & 218.32 & 203.98 & 93.42 \\
\hline $60^{\text {th }}$ & 1.135 & 1.135 & 170.97 & 163.61 & 194.05 & 185.69 & 95.69 \\
\hline
\end{tabular}

When the battery was discharged at constant current, the voltage falls slowly and the oxidized form (emeraldine salt) of PANI changed completely to the reduced form (leucoemeraldine). Thereafter, the voltage decreases rapidly and COV for the discharge process was $0.70 \mathrm{~V}$.

Based on the discharging results (Fig.-4), the Zn-PANI battery shown a specific capacity of $179.72 \mathrm{mAh}$ $g^{-1}$ at the first cycle, and $163.61 \mathrm{mAh} \mathrm{g}^{-1}$ on the $60^{\text {th }}$ cycle, where the loss of capacity up to 60 cycles is $8.96 \%$. However, in the $31^{\text {st }}$ cycle there was a capacity increase of $1.85 \%$ compared to the $1^{\text {st }}$ cycle. Then in cycles $3^{\text {rd }}$ and $43^{\text {rd }}$ show similar capacity. From these results, PANI/Zn battery performance is significantly not only influenced by the cycle process, but also the redox kinetics of $\mathrm{Zn}$ is faster than 
RASĀYAN J. Chem.

Vol. 11 | No. 4 |1525 - 1531| October - December | 2018

electrochemical degradation of PANI. ${ }^{21}$ At the $60^{\text {th }}$ charge/discharge cycle, the coulombic efficiency still keeps at $95.69 \%$, and its increases by $2.42 \%$ compared with the $1^{\text {st }}$ cycle in Table- 2 . This means that the battery has a quite good recharge performance.

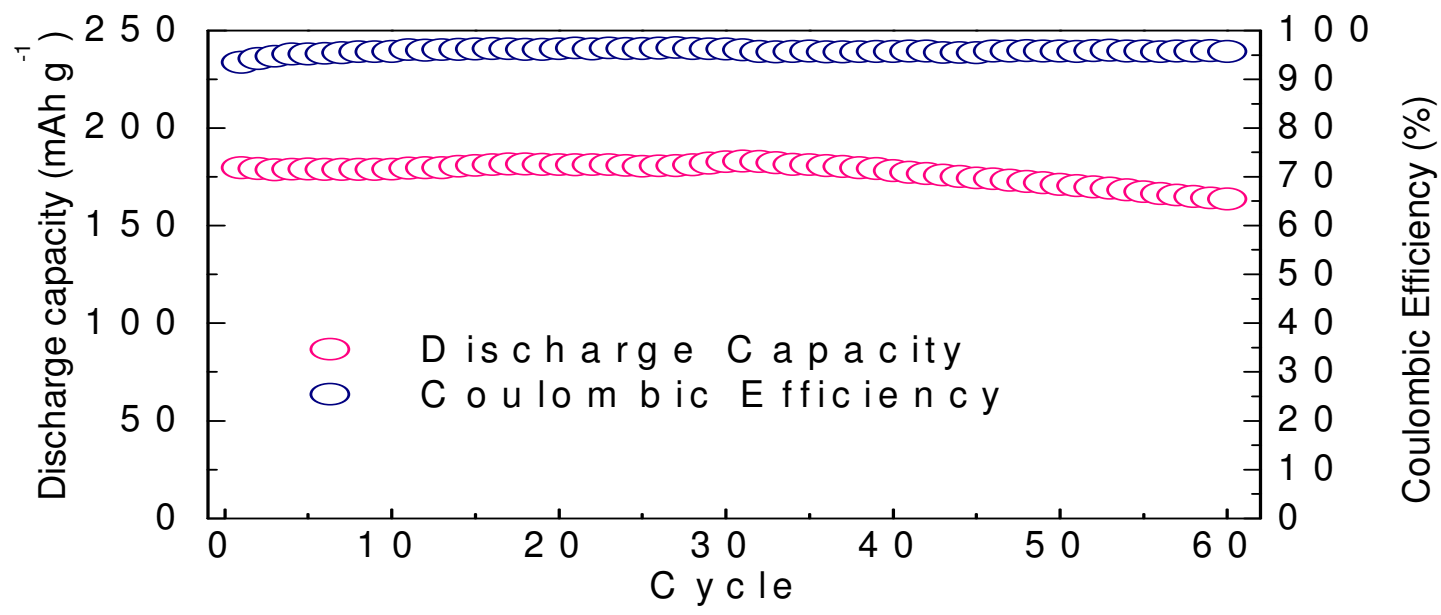

Fig.-4: Discharge Capacity and Coulombic Efficiency Vs Cycle Number for Zn-PANi Cell at a Constant Current

\section{Raman Analysis}

Density of $2.5 \mathrm{mAcm}^{-2}$. Working Voltage Range from 1.57 to $0.70 \mathrm{~V}$.

In Fig.-5, the Raman shift is mainly characterized by an intense band around $1495 \mathrm{~cm}^{-1}$ which can be attributed to the $v(C=N)$ stretching modes of semiquinoid units. ${ }^{22,25}$ This band increases when the battery has been used. This character of the emeraldin base (EB) on the PANI electrode after use in the battery was reached. The formation of EB can occur because ES lose protonation. In addition, in the band at 1188 $\mathrm{cm}^{-1}$ seen almost happened peak separation, this area is the vibration of $v(\mathrm{C}-\mathrm{H})$ benzenoid. ${ }^{17,18,23}$ Furthermore, regeneration of $\mathrm{HCl}$ in PANI electrode displays a decrease in the intensity of the Raman shift in the area. This proved the true event of protonation loss when PANI battery is used. In order to observe this better, the Raman spectra were measured on EB form in other to see differences significant differences through different pathways.

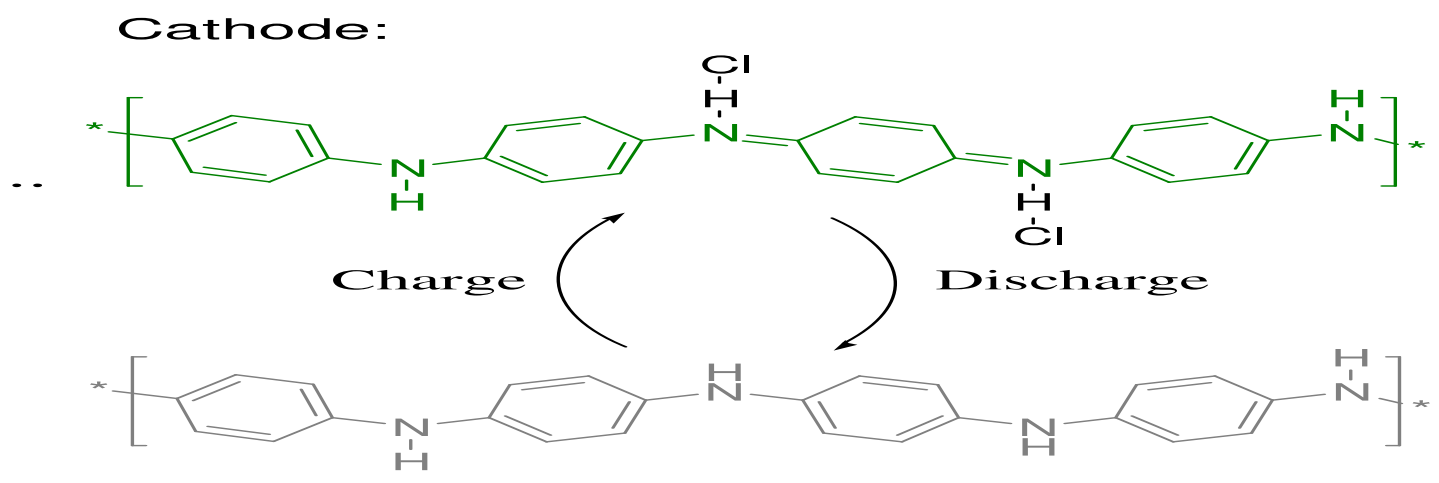

Anode:

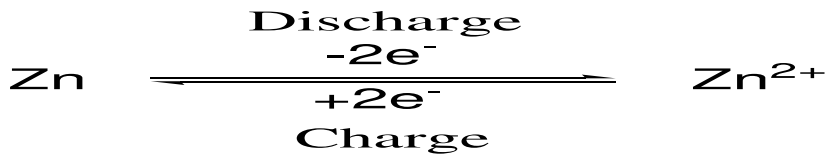

Scheme-1: Schematic Representation of Charge-Discharge Process in a Zn-PANI Rechargeable Cell.

To investigate further about this region, Raman studies were carried out on EB standard to compare with PANI electrode after using on battery (Fig.-5). The difference Raman shift of EB displayed changing contrastly through both bending and stretching areas. In the most interesting, bending area on the band at 
RASĀYAN J. Chem.

Vol. 11 | No. 4 |1525 - 1531| October - December | 2018

$415 \mathrm{~cm}^{-1}$ for EB and $409 \mathrm{~cm}^{-1}$ for PANI-Cl treatmentcorespondedwith a torque change from v(C-N-C), this vibration mode will undergo direct pertubation due to doping entry. ${ }^{12}$ It is seen that this mode undergoes softening once the protonated imine group resulted in a change the conformation of the quinonoid to semi quinonoid ring. The softening $v(\mathrm{C}-\mathrm{N}-\mathrm{C})$ torque strongly supports the long-range excitation of electrons in the ring that engaged in the conduction process. In addition, the change of the quinonoid to semi quinonoid ring as well marked the loss of the vibration peak at a shift of $771 \mathrm{~cm}^{-1}$ in EB due to its deformation in the field of quinonoid rings no longer observed on the PANI-Cl (treatment and after) spectrum, next the PANI-Cl spectrum occurs an increase in intensity on the band at $817 \mathrm{~cm}^{-1}$ wagging ring is reached. ${ }^{14}$

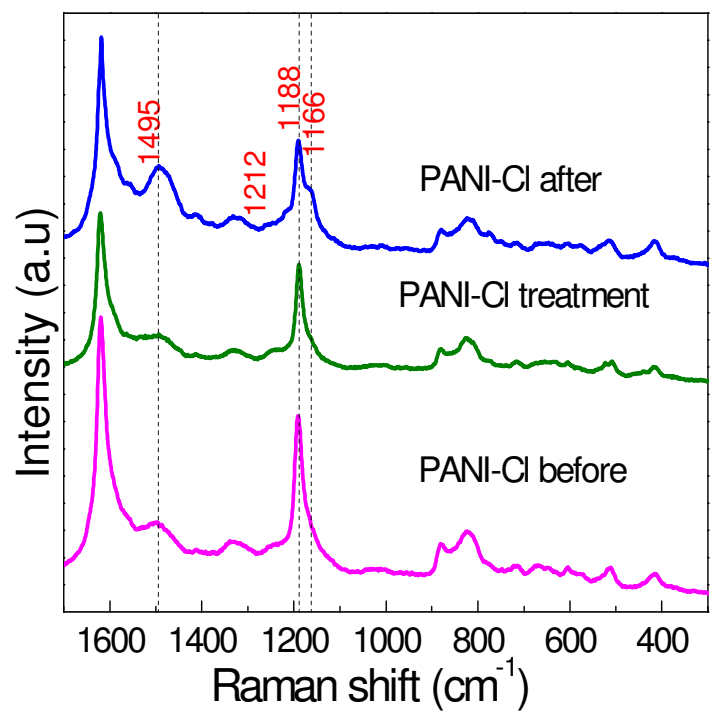

(a)

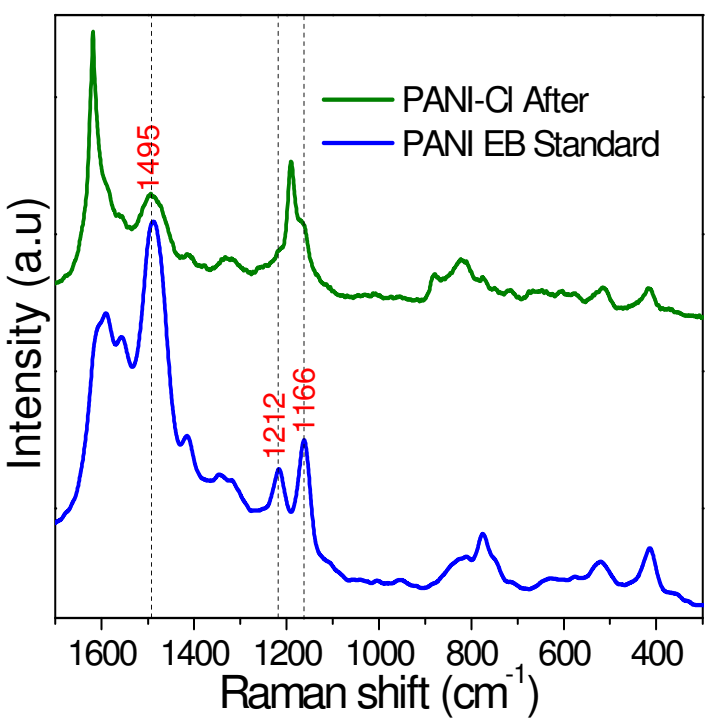

(b)

Fig.-5: Raman Spectra (Excitation Wavelength $488 \mathrm{~nm}$ ) of PANI Electrode (a) in use on Battery, (b) Comparison of PANI after use as a Battery with a Standard EB PANI.

So, Fig. -5 showing a contrast ratio between PANI after use on battery with a standard EB form, which the intensity increase at $1495 \mathrm{~cm}^{-1}$, then peak separation in the $1188 \mathrm{~cm}^{-1}$ area are very clear. The band at 1212 and $1166 \mathrm{~cm}^{-1}$ is a vibration of $\mathrm{v}(\mathrm{N}=\mathrm{Q}=\mathrm{N})$ and $\mathrm{v}(\mathrm{C}-\mathrm{H})$ on the benzenoid ring. ${ }^{19,20}$ Loss of protonation on the PANI, is possible to occur during the charging process due to its the process of filling with oxidizing of leukoemeraldine to emeraldie. ${ }^{21}$ Meanwhile, in the charging process, the PANI electrode was positively polarized so that protonation was potential easy to remove. The protonation loss was consumed by $\mathrm{Zn}$ metal, so PANI will lack the proton. At regeneration again, the decreases intensity on the band at $1495 \mathrm{~cm}^{-1}$ indicated that the vibration of the $v(\mathrm{C}=\mathrm{N})$ bond was not so noticeable because of the resonance-stabilized process of the polaron (Fig.-5).

\section{CONCLUSION}

The result of Raman analysis on PANI electrode before and after use in Zn-PANIbattery, showed an increased intensity the band at $1495 \mathrm{~cm}^{-1}$. This band corresponded with stretching mode of the $v(\mathrm{C}=\mathrm{N})$ bond. The new peak also appears on the band at 1212 and $1166 \mathrm{~cm}^{-1}$ which is the vibration of $v(\mathrm{~N}=\mathrm{Q}=\mathrm{N})$ and $v(\mathrm{C}-\mathrm{H})$ on the benzenoid ring. This indicates the formation of emeraldin bases $(\mathrm{EB})$ caused by the consumption of protons by $\mathrm{Zn}$ metal during the charging process. This fact was evidenced by decreasing the peak intensity through regenerated the PANI electrode using $\mathrm{HCl}$.

\section{ACKNOWLEDGMENT}

This work was supported by The DIKTI Grant Program 2017 with contract number 17/LPPMUSM/IX/2017 and the DIKTI Education Scholarship 2013 for its financial support in this research. 
RASĀYAN $J$. Chem.

Vol. 11 | No. 4 |1525 - 1531| October - December | 2018

\section{REFERENCES}

1. Z. Zhao, T. Yu, Y. Miao, X. Zhao, Electrochim. Acta, 270, 30(2018), DOI: 10.1016/j.electacta.2018.03.077

2. H. Gao, Q. Lu, Y. Yao, X. Wang, F. Wang, Electrochim. Acta, 232, 414 (2017), DOI: 10.1016/j.electacta.2017.02.160

3. Y. Zhao, S. Si, C. Liao, J. Power Sources, 241, 449 (2013), DOI: 10.1016/j.jpowsour.2013.04.095

4. P. Cavallo, D.F. Acevedo, M.C. Fuertes, G.J. Soler-Illia, C. Barbero, Sens Actuators B Chem., 210, 574 (2015), DOI: 10.1016/j.snb.2015.01.029

5. X. Changa, R. Hu, S. Sun, J. Liu, Y. Lei, T. Liu, L. Dong, Y. Yin, Appl. Surf. Sci., 441, 105 (2018), DOI: $10.1016 / j$. apsusc.2018.02.003

6. S.K.S. Basha, M. Gnanakiran, B.R. Kumar, K. Veera, M.V. Basaveswara, M.C. Rao, Rasayan J. Chem., 10, 1159 (2017), DOI10.7324/RJC.2017.1041756

7. R.B. Kohakade, E.S. Kumar, R.W. Gaikwad, S. Raghu, R.A. Kalaivani, Rasayan J. Chem., 10, 1151 (2017), DOI: $10.7324 /$ RJC.2017.1041881

8. C. Zhao, Y. Jin, X. Du, W. Du, J. Power Sources, 399, 337 (2018), DOI: 10.1016/j.jpowsour.2018.07.111

9. Z. Ma, J. Kan, Synth. Met., 174,58 (2013), DOI: 10.1016/j.synthmet.2013.04.005

10. G.C. Marjanovic, Synth. Met., 177, 1 (2013), DOI: 10.1016/j.synthmet.2013.06.004

11. X. Zhang, Q. Lin, X. Zhang, K. Peng. J. Power Sources, 401, 278 (2018), DOI: 10.1016/j.jpowsour.2018.08.091

12. M.R. Sovizi, Z. Fahimi, J. Taiwan Inst. Chem. Eng., 86, 270(2018), DOI: 10.1016/j.jtice.2018.03.004

13. A.H. Guo, L. Liu, Q. Wei, H. Shu, X. Yang, Z. Yang, M. Zhou, J. Tan, Z. Yan, X. Wang, Electrochim. Acta, 94, 113 (2012), DOI: 10.1016/j.electacta.2013.01.127

14. Q. Ju, Y. Shi, J. Kan, Synth. Met., 178, 27 (2013), DOI: 10.1016/j.synthmet.2013.06.016

15. S.A. Akbar, A. Mardhiah, N. Saidi, L. Lelifajri. In Prosiding Seminar Nasional USM, Aceh, Indonesia, pp. 557-559 (2017), DOI: ojs.serambimekkah.ac.id/index.php/semnas/article/view/433

16. Y. Wang, K. Levon, Macromol Symp, 317, 240 (2012), DOI: 10.1002/masy.201200008

17. M. Tagowska, B. Palys, K. Jackowska, Synth. Met., 142, 223 (2014), DOI: 10.1016/j.synthmet.2003.09.001

18. A. Rochliadi, S.A. Akbar, V. Suendo. In Proceedings of the Joint International Conference on Electric Vehicular Technology and Industrial, Mechanical, Electrical and Chemical Engineering (ICEVT \& IMECE), Surakarta, Indonesia, pp. 353 (2015), DOI: 10.1109/ICEVTIMECE.2015.7496686

19. Y. Chen, S. Manzhos. J. Power Sources, 336, 126 (2016), DOI: 10.1016/j.jpowsour.2016.10.066

20. J. Luo, W. Zhong, Y. Zou, C. Xiong, W. Yang. J. Power Sources, 319, 73(2016), DOI: 10.1016/j.jpowsour.2016.04.004

21. H. Kawashima, R. Okatani, H. Mayama, Y. Nakamura, S. Fujii. Polymer, 148, 217 (2018), DOI: 10.1016/j.polymer.2018.06.039

22. K.V. Kurada, S. De, Polymer, 153, 201(2018), DOI: 10.1016/j.polymer.2018.08.032

23. I. Šeděnková, M. Trchová, J. Dybal, J. Stejskal, Polym. Degrad. Stab., 134, 357(2016), DOI: 10.1016/j.polymdegradstab.2016.11.005

24. C. Oueiny, S. Berlioz, F.X. Perrin. Prog. Polym. Sci., 39, 707(2014), DOI: 10.1016/j.progpolymsci.2013.08.009

25. J. Stejskal, Prog. Polym. Sci., 41, 1(2015), DOI: 10.1016/j.progpolymsci.2014.10.007

[RJC-4064/2018] 